\title{
PRACTICAL ASPECTS OF SOME LEGAL PROBLEMS OF SALES FINANCE COMPANIES*
}

\author{
JOSEPH G. MYERSON†
}

Mr. Adelson's article indicates a careful study of available literature and no substantial exception may be taken to its conclusions which accurately reflect the law and practice to which they are addressed. It is apparent that in recent years a vast number of cases have been reported involving the instalment contract." What does not appear, however, is that there were even a larger number of cases tried in the lower courts which did not reach the higher courts and so are not reported. Analysis of this great volume of litigation and the large amount of literature on the subject discloses that there is room for improvement in the law both by way of correction of existing statutes and by way of enactment of new legislation. Such cases, too, have engendered a practical approach to some of these problems which may be of interest.

\section{REPOSSESSION}

A prolific source of dispute and misunderstanding is the matter of repossession after default. We may start with the presumption that the legitimate finance company does not repossess equipment except as a last resort. If he has indicated a desire to continue his payments and the moral hazard is reasonably favorable every opportunity is given to the defaulting purchaser to make his payments. This may take the form of rewriting the schedule of payments for the remaining balance due under the contract or it may consist of a definite extension of time for particular instalments, or the postponement of several payments until a later time, generally after the last payment has matured under the contract as written. But where the purchaser is chronically in default month after month, where there is a reasonable suspicion of conversion hazard or where it is evident that a purchaser for one reason or another, such, for example, as loss of employment, definitely will not be able to make his payments, repossession will in all probability ensue. Here the representative of the

- EDIToR's Note: Galley proof of the preceding article, The Mechanics of the Instalment Credit Sale, by Mr. M. William Adelson, was submitted to Mr. Myerson with a request for his comments. Unfortunately, the circumstances of publication were such as to afford Mr. Myerson only a limited period of time for review and comment.

TLI.B., New York Law School. Member of New York Bar. Assistant General Attorney, C. I. T. Corporation. Member of National Conference Street and Highway Safety, 1926, 1930, 1934. Contributor to Iegal periodicals. 
finance company must determine whether it is economically sound to permit a defaulting purchaser to continue in possession, regardless of importunities which frequently. may quicken his sympathy. It is hard to deprive a man of property for which he has sometimes paid a substantial amount of money-even though compensated for, at least in part-by the use of the property prior to the loss of possession.

It is a happy circumstance of repossession experience that in the great majority of repossessions without legal process there is a voluntary surrender of the property to the finance company. Not infrequently a purchaser who is unable to continue his payments drives the car to the place of business of the finance company and invites or requests repossession so that he may be relieved of his responsibility of further payments. Of course, it does not always follow that such a voluntary surrender discharges the obligation, for in those states where the law does not require an election of remedies, the car is sold either according to the requirements of statute or according to the provisions of the contract, and if the purchaser is financially responsible he may be followed for the deficiency. In many cases, however, of voluntary repossession the purchaser signs a waiver of statutory resale of the automobile and consents to a private resale, in consideration of which the holder of the contract releases the purchaser from all further liability.

But where the owner does not voluntarily surrender the property, what is the practice? Of course, if repossession may be had without resort to legal procedure it is desirable, from the point of view both of the holder of the contract and of the purchaser. The purchaser benefits because any expense which is involved in the repossession or litigation is charged against the account, resulting in a larger deficiency, for which action may subsequently be brought. Replevin or claim and delivery action is costly. We note that Mr. Adelson refers to the cost of these proceedings as ranging from $\$ 2.50$ to $\$ 7.00$. $^{1}$ More often the costs will run substantially beyond $\$ 7.00$. The plaintiff is required to post a bond and it is the practice (of the larger companies at least) to furnish a surety company bond rather than the personal bond of an officer or employee. The minimum premium is $\$ 10.00$ except where the property is valued at less than $\$ 250.00$, in which case a premium rate of $\$ 5.00$ is sometimes available. The statutory fees of the sheriff are generally not very high and perhaps from $\$ 5.00$ to $\$ 7.50$ would cover except that in practice it has been found that many sheriffs or constables will not give adequate or satisfactory service for the statutory fee, and a gratuity of $\$ 5.00$ or $\$ 10.00$ is frequently necessary if proper attention to a writ is to be expected. Add to this the attorney's fees and it becomes apparent that replevin proceedings are an expense to be avoided if at all possible.

Practically all states permit repossession of the property covered by the contract by self help, provided the repossession can be effected without breach of the peace. Despite the protection thus afforded by law, repossession by self help occasionally creates troublesome situations. Great care is exercised by the finance companies that

\footnotetext{
${ }^{1}$ See Adelson, The Mechanics of the Instalment Credit Sale, supra at p. 236.
} 
no right of the purchaser may be invaded. Detailed instructions are given to company adjusters or representatives advising them specifically what they may or may not do. They are told, for example, that they may not break into a garage or other enclosure; that if the purchaser makes objection to the repossession the attempt to repossess must be abandoned forthwith, so that the possibility of a physical encounter is eliminated. While it may be that mere objections or protests of the conditional purchaser do not make an otherwise rightful taking wrongful, the finance companies have felt that taking of property in the face of objection or protest so closely approaches a breach of the peace and may so readily be expanded into a serious situation that, as indicated, the instructions are to abandon an attempted repossession under such circumstances; the exercise of force is at all times forbidden to a company adjuster. This does not mean that force is not sometimes exhibited, but the force is in the direction of purchaser to adjuster rather than adjuster to purchaser. Only a very few instances have come to the writer's attention over an experience of twenty years where purchasers have claimed that an assault was made upon them by a company employee and in each of these cases, thorough investigation indicated that the purchaser, and not the adjuster, was the aggressor. In one case, where an adjuster was arrested for such an alleged assault, he was discharged and completely exonerated, and the complaining witness, the purchaser, himself held on a charge of assault.

It will be seen then that the responsible finance company makes every effort to see that repossessions are peaceable, not in any restricted technical sense, but peaceable as the layman understands that term.

Where trouble is anticipated, even in the case of a repossession to be accomplished through the medium of a court writ, adjusters have been instructed, and make it a practice, to ask a local police officer to assist. Sometimes this does not work out, as in one case where a purchaser refused to get out of an automobile and a police officer standing by told the adjuster to go ahead and take the machine with the purchaser in it. Fortunately, the adjuster had too much good sense to follow the police officer's instructions. On the whole, it has been found helpful only in the occasional case to have a police officer present at the time of repossession. It would be most unfortunate, however, if the presence of a police officer were in all cases to be required. It is embarrassing for an honest citizen to have a police officer involved in his affairs and since it is only the exceptional case in connection with which the presence of a police officer might be advisable, it is evident that such a requirement is unnecessary and would do more harm than good.

Repossessions are reported to the Police Department promptly, especially in the large metropolitan sections. A purchaser whose car is repossessed from the street may report it as a theft, and it is a relief to him and to the Police Department when such report is made that the Police Department already has received a record of the recapture of the car from the holder of the contract, so that the machinery for 
recovering stolen automobiles is not needlessly put into motion. The police are also notified in the case of repossession of an automobile in which personal property may be found. This, however, is done only where the purchaser cannot be located promptly and the property returned to him. Scrupulous investigation is made of all claims for loss of personal property. The finance company of course does not want to take property belonging to the purchaser and equally important, it wants to discover the fact if one of its employees is dishonest and takes such property without reporting it. In only one case out of all of these was it found that the purchaser's claim was well founded. In that case restitution was made and the adjuster was discharged. All other cases were resisted to the point of defending litigation, in which except in one instance, the fraudulent nature of the claim was disclosed.

Repossession having been made a purchaser may generally redeem his automobile upon payment of the delinquent instalments and the actual expense of repossession. In figuring these repossession expenses the purchaser is not "soaked," but a reasonable charge is made covering actual disbursements and the adjuster's time. If the account has been a bad one, however, the purchaser may not have the car upon payment of the delinquent instalments, but payment of the full outstanding balance is required. This, however, is not usual, and only where the delinquency is quite aggravated or the situation involves a condition of "insecurity" do the reputable companies insist upon payment in full.

It will be seen from all of this that the holder of the conditional sale contract is zealous to see that the purchaser who finds himself unable to meet his instalments promptly is given every opportunity to keep his property and that every effort is made to avoid even a semblance of abuse.

\section{Garage LIENS}

Incidental to this question of repossession is the problem of garage liens. As has been indicated in Mr. Adelson's article, ${ }^{2}$ many states give some degree of priority to the lien of a repair or storage man over the lien of a conditional sale contract. The honest garage lien presents few difficulties. It is either paid or adjusted, depending on circumstance. There has, however, especially in the large cosmopolitan centers grown up what may be called the garage lien racket. Here the garageman who is given a limited priority, as for example in New York, where the priority is for services and materials furnished within a thirty day period, ${ }^{3}$ has learned to avoid the limitations of the law by "faking" his bill. If he has a legitimate bill running over a period of more than thirty days he will make up a false bill putting all of the items in during the thirty day period, indicating perhaps a "fake" repair or an excessive use of oil and gas during that period to make up what he is not entitled to under the law. Frequently garage bills or claims are made up out of the whole cloth, or are "grossly exaggerated," as for example in C. I. T. Corporation v. Solomon." In such

${ }^{2}$ Id. $2 t$ p. 242.

'N. Y. Cons. Laws (Cahill, I930) c. 34, \$184. 'I52 Mise. 833, 273 N. Y. Supp 563 (1934). 
cases the holder of the conditional sale contract must be alert if he is to avoid paying fraudulent garage bills. A physical examination of the car does not always assist, because a smart repairman can make it appear that he has dismantled and remounted a motor or rear end when in fact he did nothing more than remove a few bolts and ${ }^{\circ}$ wipe away some grease.

Where the holder of the contract is convinced that the garageman is claiming more than he is entitled to (and this is likewise true where a garageman refuses to give the car up to the holder of the contract, even though he is offered the full amount of his bill), it has been found helpful to make written demand upon the garageman for possession of the car accompanying the demand by a legal tender of such amount as the holder of the contract believes the lien holder is actually entitled to receive. The written demand gives the garageman a reasonable opportunity, forty-eight hours or seventy-two hours, as the circumstances may indicate, to determine whether or not to honor the claim made for the car and offers indemnity against other claimants. If this demand does not result in release of the machine replevin may be brought against the garageman. It has been held that under such circumstances (the court finding that the amount of his actual lien as adjudicated was tendered to the garageman either with or without an excessive claim having been made) he loses his lien and his refusal to give the car up amounts to a conversion of the property.

While this procedure is helpful in some cases it has been found that a coldly practical attitude toward the garageman and "speaking his own language" are the best means of avoiding heavy assessments in this direction.

\section{Mrsuse of Automobire by Purchaser}

Of course, repossession is made not alone for default in payment, but sometimes for breach of some other provision of the contract. The provisions most frequently violated, necessitative repossession, are those against transfer of the property without the consent of the holder of the contract and the improper or illegal use of the automobile either for purposes of taxi or hire or for actual law violation, such as bootlegging or the carrying of narcotics.

The hazards in the use of an automobile for hire are so much greater than those in the use of an automobile for passenger purposes that the sellers must receive a higher financing charge on such sales. Where the purpose is concealed at the time of sale and the facts are later brought home to the holder of the contract prompt repossession will usually follow.

A recent hazard in connection with the use of cars for hire has been the development of the drive-yourself business. Some dealers made it a practice of selling to drive-yourself organizations concealing the true purpose by having individual employees of one organization or the other act as the ostensible purchaser. Sometimes

${ }^{8}$ C. I. T. Corp. v. Isham Park Garage, Inc., 134 Misc. 50x, 235 N. Y. Supp. 163 (1929). 
as many as fifteen or twenty automobiles have been recovered by various finance companies from single drive-yourself organizations in drives to eliminate this type of fraud.

The bootleg situation of course represents a real hazard. Unfortunately, the repeal of the prohibition amendment, instead of being beneficial to contract holders, has operated to their distinct disadvantage. To begin with, seizures of automobiles for violation of the revenue laws continue in substantial numbers despite repeal of the I8th Amendment. The National Prohibition Ȧct, by Section $26,{ }^{8}$ provided in effect that a lienor who could prove to the satisfaction of the court that his lien on the automobile had been created in good faith and without any knowledge of the intended illegal use of the car was protected and could either have his property returned to him if it was appraised at less than the amount of the lien or could have the amount of the lien paid out of the proceeds of the sale if it was appraised at a higher figure. The full benefits of this provision were obtained by virtue of the decision in Richbourg Motor Company v. United States, ${ }^{7}$ which in effect held that where a violation of the prohibition law was indicated in the circumstances surrounding the seizure, the Government was bound to proceed for forfeiture of the automobile under the provisions of Section 26 of the Prohibition Act and could not proceed under the provisions of the Internal Revenue Act sections, ${ }^{8}$ which provide for an absolute forfeiture. Prior to that decision it had been the practice of the Government to proceed for forfeiture of automobiles under Section 3450 of the Revised Statutes, ${ }^{9}$ a tax evasion statute the application of which resulted in absolute confiscation regardless of the good faith or innocence of a lienor or owner. With the repeal of prohibition, however, the law established by the Richbourg decision became a "dead letter," and the Government has been free to proceed under the Revenue Act, the only right of an aggrieved lienor being to apply to the Secretary of the Treasury for remission, pursuant to Section 709 of the Revenue Act of 1928.10 Because of its interpretation by the Department, this procedure has proved utterly inadequate and unsatisfactory. As pointed out by Mr. Adelson, ${ }^{11}$ the decision of the Secretary of the Treasury is not subject to review by the courts and no matter how arbitrary the decision of the Secretary may be, the decision stands. Under the statute, it is provided that the Secretary of the Treasury, on petition, may grant relief where a petitioner can show that he is free from wilful negligence in connection with the sale of the automobile which has been seized and forfeited. Interpreting this statute, the Secretary of the Treasury requires the petitioner to show that prior to the sale of the automobile he communicated with the law enforcement agencies and made inquiry as to the reputed bootlegging activities of the prospective purchaser.

${ }_{41}^{4}$ Stat. 315 (x919), 27 U. S. C. A. $\$ 40$.

$7_{28}$ U. U. 528 (1930).

414 SIAT. 151 (1878);26 U. S. C. A. $\$ \$ I 8 I-I I 82$.

Ilbid.

${ }^{10} 45$ STAт. 882 (1928), 26 U. S. C. A. \$2709. $\quad{ }^{11}$ See Adelson, supra note I, at p. 230, n. 73. 
When it is realized that in 1934 approximately $2,500,000$ automobiles were sold to instalment purchasers, the impossibility of making such inquiry of the enforcement agencies becomes apparent, but nevertheless the interpretation stands, resulting in denial of relief in case after case involving a meritorious claim. These petitions and the inquiry as to the bona fides of the claimant are judicial or quasi-judicial in character and belong in the courts and not in the Department of the Treasury. It is hoped that legislation now before Congress will be enacted restoring to the courts the right to pass upon claims of this nature.

\section{Confession of Judgment and Watver Clauses in Notes}

It has been observed by $\mathrm{Mr}$. Adelson ${ }^{12}$ that the form of note and instrument generally employed in instalment sales contains a confession of judgment clause and a waiver of exemption and homestead rights. As to the latter, the reputable sales finance companies seldom, if ever, enforce it. The clause is retained, however, because on rare occasions it may be found helpful in defeating the fraudulent effort of debtors to dispose of their property and thus prevent the satisfaction of claims against them. Our own company has taken advantage of this waiver clause on only two occasions that the writer can recall, both involving instances of that kind. By and large, the consideration given to the debtor by the sales finance company goes beyond the exemptions granted him by law, and not infrequently the larger finance companies voluntarily write off and accept as losses open balances which might perhaps be collected if the contract holder had availed itself of all of the rights and remedies afforded by the contract.

As to the confession of judgment clause, this likewise is a defensive rather than an offensive device. It is true that instead of repossessing the property and suing for a deficiency the holder of a contract will sometimes enter the note for judgment and levy upon other property of the debtor, but this is the exception rather than the rule. The confession of judgment justifies its inclusion in the contract form for use in the case where the holder of the contract has reason to anticipate that the debtor intends to transfer property to defeat the rights of or defraud his creditor. In such cases the note is entered for judgment at once, thus creating a lien against the property and preventing its fraudulent conveyance. As $\mathrm{Mr}$. Adelson points out, ${ }^{12}$ most of the courts permit a judgment entered upon a note of this kind to be opened and a defense interposed when the debtor can prove that a bona fide defense is available.

\section{Recording and Certificate of Title Legislation}

It may be assumed that the essential purpose of a filing or recording statute is to prevent the fraudulent transfer of property held subject to an encumbrance. The filing laws, however, are so ill-suited to our far-flung commercial activities that this purpose of the statutes fails utterly, and this is especially true in the case of auto-

\footnotetext{
2Id. at p. 223.
}

Is Id. $2 t$ p. 224 , n. 3 I. 
mobiles. Most filing statutes require filing or recording in the place of residence. Specifically the filing may be required in the town where the purchaser resides or the county seat of the county where he resides. In the one case there may be as many as two thousand individual filing places in a state, in the other, as many as one hundred and fifty. Surely a person endeavoring to buy an automobile should not be required to check the records in all of these places; yet, only such a comprehensive search would be effective, for while the fraudulently-minded conditional purchaser may actually reside in one county and a contract be filed in that county, nevertheless when selling the car he will give his residence as at some other point (from which he has falsely registered it) and there of course no filing will be found.

To meet modern conditions central filing of automobile contracts has been developed. In the State of California, which is a pioneer in this type of legislation under the able sponsorship of J. Allen Davis, Counsel for the Automobile Club of Southern California, provision is made for the filing of automobile chattel mortgages with the Division of Motor Vehicles. ${ }^{14}$ This makes it easy for one who wishes to buy a car to check the records at one central point and prevents the perpetration of fraud through concealment of actual residence.

A logical development of central filing is the coupling of that provision with the certificate of title. The certificate of title has been developed in recent years as an anti-theft device. Potentially it is far more effective as a preventive measure than is the Dyer $\mathrm{Act}^{15}$ as a remedial measure, and if the law were adopted in all of the states interstate traffic in stolen automobiles would virtually disappear. The mechanics of the Certificate of Title Law are simple. When the owner of an automobile registers his machine he also applies for and receives a certificate of title. The registration gives him the right to run the machine on the highways of the state, whereas the certificate of title indicates his right of ownership and possession. The certificate indicates encumbrances and liens so that when a man wishes to sell his car and exhibits his certificate of title for that purpose the purchaser is at once put on notice that the car is subject to the indicated encumbrance. However, this system does not prevent fraud. A purchaser may apply for a clear certificate of title, concealing the lien which consequently will not appear on the face of the certificate, and may use the clear certificate to persuade a victim that the car is unencumbered. If as a matter of fact the car is held under a contract filed in the office of the statutory recording officer, the lienholder will generally prevail. If, however, the filing, as suggested below, were with the officer who issues the certificate and who co-incident with the filing would as a matter of course indicate the lien on the certificate, such frauds would be made impossible.

For this reason it has been urged that in addition to the notation of the encumbrance on the certificate of title the Bureau of Highways or such other department as

${ }^{24}$ Cax. GEN. Laws (Deering, I93I) act 5r28, 5451/4.

${ }^{15}$ 4I STAT. 324 (I9x9), I8 U. S. C. A. $\$ 408$. 
may have control of certificates of title act as a central filing or recording point of - contracts affecting automobiles. The importance of this problem was recognized by the Fourth National Conference on Street and Highway Safety in May, 1934, and in its most recent revision of the Uniform Certificate of Title and Anti-Theft Act there were included sections 64 and 65 which provide for such central filing and which make filing under any other existing state statutes unnecessary.

We look forward to the time when this uniform legislation will provide not only certificates of title for all of the states, but also the central filing provision. When that time comes dishonest contract purchasers will find it impossible to victimize the gullible by selling automobiles they do not own.

\section{The Distinction Between Sales and Loan Finance Companies}

The relationship between the "finance company" and the consumer public has been misunderstood. Probably the underlying reason is due to the fault of neither but to the presence of a third.factor, to wit, the loan company. In this article frequent use has been made of the term "finance company." It should be understood that this term refers to "sales finance company" as distinguished from "loan finance company." The sales finance company purchases from the seller of a commodity the contract or time payment document given to secure the unpaid balance. The loan company makes a direct loan to the owner of a commodity who may be obtaining the loan because of family emergencies or pressure of debts; or the borrower on occasion may be a purchaser obtaining the loan to pay a balance due on a contract held by a sales finance company which for reasons suggested above, may be requiring payment of the full balance following default. It is obvious that whereas the sales finance company acquires the contract of a consumer believed to be a solvent risk who may be expected to pay his obligation as he contracts to pay it, the loan company transacts its business with a necessitous borrower, knowing him to be such. It follows that the collection methods employed by the two types of companies are distinct; inherent in the loan company situation lies the possibility of collection practices which lead to resentment and complaint on the part of the borrower. These complaints, by reason of ignorance of the distinction between sales finance companies and loan companies, and also because many of the latter masquerade under a false title, are accepted by legislators and the public as being directed in a broad sense against "finance companies." As a result the sales finance company suffers for the dissatisfactions arising out of the nature of the business of the loan company.

Freedom of the operations of sales finance companies from abusive practices is due to a combination of factors. First is the circumstance that these companies (this is true of all of the larger or national companies and is generally true of the other companies) have been established for many years, were organized on a sound business and ethical basis, and are controlled by business men who from an inherent 
sense of social responsibility properly conduct themselves toward those with whom they transact business. A second circumstance which leads to the high plane upon which the.business is conducted is the fact that there are relatively few defaulting purchasers; the type of person who buys a commodity involving a substantial expense, is apt to be one in whom a proper course of conduct strikes a responsive note.

A third factor is that the sales finance companies perform an important function in helping move the product of the manufacturer and in facilitating the success of its sales organization. The finance company is not part and parcel of the organization which makes the sale, but the sales finance industry is regarded as a virtual arm of the manufacturing and selling industry. The sales finance company is interested in getting the merchandise sold and in keeping the customer satisfied: The loan company is neither motivated nor restrained by any such considerations. That.being so, regardless of the extent to which the sales finance company is prompted by an inherent regard for the rights of those whose obligations it holds, it must in the performance of its function as the financial "adjunct" to the manufacturer and merchant preserve for them the good will of the buying public. 